\title{
INFLUENCE OF EMPLOYEE ENGAGEMENT AND EMPLOYEE BENEFIT SCHEMES ON JOB SATISFACTION
}

\author{
aALICE REISSOVÁ, ${ }^{\mathrm{b}} J A N A$ ŠIMSOVÁ, ${ }^{\mathrm{C}}$ KAROLÍNA \\ FRIČKOVÁ
}

Jan Evangelista Purkyně University in Ústí nad Labem, Faculty of Social and Economic Studies, Moskevská 54, 40096 Ústí nad Labem

email: ${ }^{a}$ alice.reissova@ujep.cz, ${ }^{b}$ jana.simsova@ujep.cz,

crickova.k@gmail.com

\begin{abstract}
Currently, there are shortages of qualified labour on the market. Businesses struggle to attract new employees, which is why they strive to retain their current employees. They pay great attention to overall job satisfaction of their employees. Satisfaction of employees can be affected by their engagement or rate of satisfaction with employee benefits. The objective of the study was to identify whether the overall job satisfaction of line employees in a manufacturing corporation is influenced more by employee engagement or satisfaction with the benefit scheme. The applied linear regression shows that a benefit scheme affects the increase in overall satisfaction less than the assessment of engagement at work. Employee engagement was monitored in three areas: satisfaction with management, work atmosphere and potential personnel turnover rate. The largest influence was reported in the assessment of the work atmosphere. Another important finding is a statistically significant difference between the assessment of work atmosphere given by Generation $\mathrm{X}$ and $\mathrm{Y}$. If employers want to manage work performance efficiently, they should respect the differences between these generations when preparing incentive schemes. The issue should be examined in the field of science and research as well.
\end{abstract}

Keywords: job satisfaction, employee engagement, benefits, Generation X, Generation $\mathrm{Y}$, work atmosphere

\section{Introduction}

The unemployment rate in the Czech Republic has been declining over a long period of time. The data provided by the Czech Statistical Office at the turn of the years 2018 and 2019 show that it has dropped to $2 \%$ (CZSO, 2019). A low unemployment rate is a sign of economic prosperity, which is a positive trend, however, it entails particular difficulties when attracting new staff members or retaining existing employees considering human resource management. With more or less the same manning levels in a specific locality/region, the demand for labour is growing. Consequently, employers put great emphasis on caring for their employees and a number of financial indices which can indicate a potential risk. Such indices may comprise monitoring of overall employee satisfaction, employee satisfaction with the benefit scheme in place or employee engagement.

Engaged staff members are devoted, energetic and committed to their job. Work engagement positively affects the work atmosphere, safety at work, relationships with peers and career opportunities. On the other hand, poor relationships at work, a negative work atmosphere or high demands at work can result in personnel fatigue (Petrović et al., 2017). Ćulibrk et al. (2018) state that engagement is the condition when satisfied personnel have a positive attitude not only to their job, but also to the whole organization. Madan (2017) formulated a recommendation on how to increase employee engagement. He says employers should focus on several fundamental areas: respecting employees (appreciated respect increases their loyalty), fair treatment, objective assessment of employee performance, a fair remuneration policy (both tangible and intangible) and care for the health and social needs of the personnel. Other important conditions for increasing employee engagement is awareness of employees (setting communication channels correctly, feedback in place), involving employees in what is happening in the organization and, last but not least, a good employer reputation (Madan, 2017).

Job satisfaction is one frequently monitored factor at work, particularly at a time of high demand for labour on the labour market when it is very easy to change employer (Gosse \& Hurson, 2016). Satisfied personnel are a major driver of an organization (Rani et al., 2011). Hence, companies should focus on personnel satisfaction (Cimperman, 2016). Satisfied personnel generate long-term productivity (Borcherding \&
Oglesby 1974; Shikdar \& Das 2003, cit. Albattah et al., 2017) and efficiency of an organization (Minder \& Balina, 2015). It has been verified that satisfied personnel are usually more creative, come up with new ideas and are a source of innovation. On the other hand, employee dissatisfaction results in stagnation (Prayogo et al., 2017). Culibrk et al. (2018) state that job satisfaction is a key element in personnel motivation. Job satisfaction is substantially affected by factors such as working environment, relationships at work or financial and social factors. It is therefore crucial to know what the expectations of personnel are and then try to respond to their requirements (Aksoy et al., 2018).

Employee satisfaction can undoubtedly be increased using a variety of tangible and intangible rewards as part of an incentive scheme. Since employers spend considerable amounts on motivating their personnel, the incentive scheme should be regularly monitored and evaluated so that it responds to changes (Hitka et al., 2015). The most frequent employee benefits offered by organizations to employees are contributions towards catering, pension and life insurance, contributions to cultural events or holidays and sports. Sick days, employer's contributions to pension schemes and language courses are the most desired benefits (Němečková, 2016). The benefit scheme can also include longer annual leave or other contributions (such as to living, transport or education). Employees who prefer a healthy lifestyle will appreciate contributions to sports activities or contributions focusing on health, such as rehabilitation, supplemental health care, vaccinations, or contributions to buying vitamins for employees (d'Ambrosová, 2015). As mentioned above, employee satisfaction is crucial. However, the question is whether job satisfaction is affected more by employee engagement or the benefits offered by the employer, into which it usually invests a considerable amount of money. The objective of this study is to answer the question.

\section{Methodology}

The objective of this study is to identify whether the level of engagement of line employees in a selected business enterprise has a greater impact on their overall job satisfaction than the level of satisfaction with the available benefit scheme.

The investigation was carried out in a manufacturing corporation which has 478 line employees (mostly men). The method of written questionnaires was selected to collect data. Firstly, respondents used a four-level scale (strongly agree to strongly disagree) to answer the question whether they are satisfied with the employee benefits offered by their organization. The next question to answer was related to their overall satisfaction in their organization. They responded using a scale of $1-100 \%$, where $1 \%$ means that a respondent is definitely not generally satisfied, and $100 \%$ means that a respondent is completely satisfied. The same scale was used to answer the question about their current overall satisfaction with the employee benefit scheme. Further questions focused on employee engagement, which was investigated in three areas - work atmosphere, satisfaction with management and potential personnel turnover. A four-level scale ranging from strongly agree to strongly disagree was used to answer the questions. As to the work atmosphere, respondents answered questions such as whether they have good colleagues at work, whether their colleagues are willing to perform well, whether there is usually a good atmosphere among colleagues at work or whether they learned something new at work in the past. As to satisfaction with management, respondents answered the question of whether their opinion is valued, whether their superior managers are interested in them as human beings, whether their good performance is recognised by their superiors, whether their superiors encourage their personal development, or whether they think their organization enjoys a good reputation. Questions focused on potential personnel turnover answered by the 
respondents were - would you leave your current job if a comparable job was offered to you, have you considered leaving the job over the last 6 months, are you currently looking for another job, or do you think colleagues often leave jobs in this company. The questions relating to engagement were taken from expert studies (Reissová, Šmsová, Hášová, 2017a; Lee et al., 2017). At the end of the questionnaire research, the respondents answered identification questions, specifically, they were asked about their length of employment with the organization, the department they work in, age, gender and the highest education achieved.

The data were collected in May 2018. The selection group consisted of 212 blue-collar workers. The survey response rate was $69.7 \%$. Of the total number of respondents $91 \%$ were men and $9 \%$ women. Of these respondents, $25 \%$ of the workers were aged between 15 and 29, $42 \%$ of the workers between 30 and 40, $24 \%$ between 41 and 50 and $9 \%$ of the workers were aged 51 or more. With regards to the length of employment, 15 $\%$ of respondents have been working for the company for less than 12 months, $15 \% 1$ to 3 years, $46 \%$ of respondents between 4 and 14 years and $23 \%$ for 15 or more years. Most of the respondents completed secondary schools with a certificate of apprenticeship (71\%). $21 \%$ of respondents have a certificate of secondary school leaving education. $4 \%$ have completed elementary education and $3 \%$ of respondents are university graduates.

MS Excel and MS Statistika were used to collect and process the data. Statistical methods of the linear regression, F-test of overall significance in regression analysis and the Mann-Whitney $\mathrm{U}$ test were used to evaluate the data.

\section{Results}

The description of dependence of the overall job satisfaction on the satisfaction of employees with the benefit scheme was established using the linear regression. The most suitable regression function was a linear function. We looked for the impact model of the "employee engagement on their overall job satisfaction". As to satisfaction with the employee benefit scheme, the resulting correlation coefficient was 0.482 , which means an averagely strong dependence between the variables of Satisfaction with the employee benefit scheme and Overall job satisfaction. The p-value of the F-test was $1.39 * 10-13$ in this case, which means that the model is statistically significant when compared to the significance level of 0.05 . The dependence of overall job satisfaction and satisfaction with the employee benefit scheme can be described using the following function: $y=21.425 x-1.0317$. The graphic representation of the regression model depicting the dependence between overall job satisfaction and satisfaction with the benefit scheme is shown in Figure 1.

Fig. 1: Regression model of dependence between overall job satisfaction and satisfaction with benefits

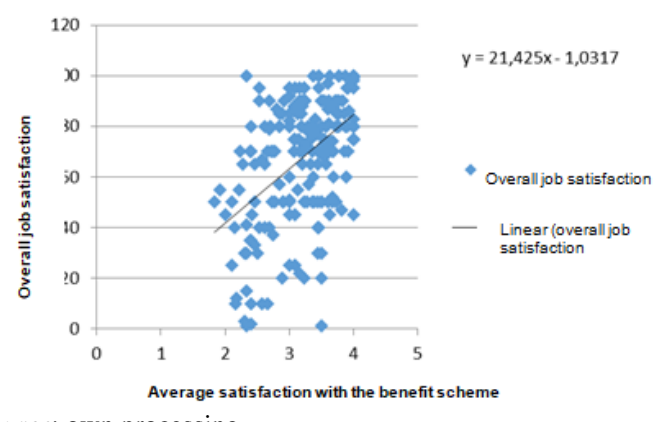

Source: own processing

A correlation coefficient of 0.709 was established in employee engagement, which suggests a strong linear dependence between the variables of Employee engagement and Overall job satisfaction. The p-value of the F-test was very low here too, namely $2.57 * 10-33$, which confirms that the model is statistically significant when compared to the 0.05 significance level. The results also show that an increase in the assessment of the engagement of one unit is followed by an increase in the overall job satisfaction of $28.8 \%$ and an increase in the assessment of the satisfaction with the employee benefit scheme of one unit is followed by an increase in the overall job satisfaction of $21 \%$. The dependence between overall job satisfaction and employee engagement can be expressed using the function: $y=28.787 x-10.5$. The regression model of the dependence between overall job satisfaction and employee engagement is shown in Figure 2 in the graph below.

Fig. 2: Regression model of the dependence between overall job satisfaction and employee engagement

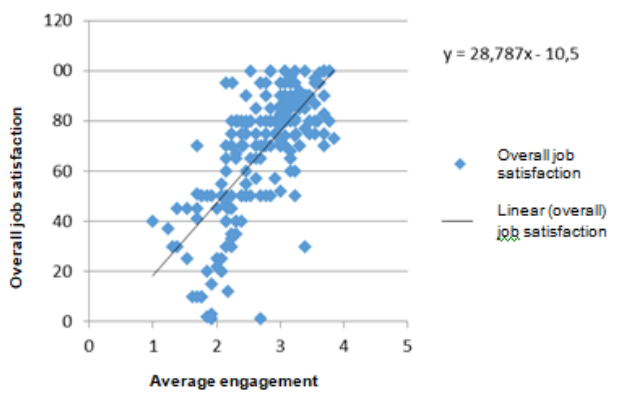

Source: own processing

Consequently, we looked for the model of dependence of "Overall job satisfaction on the Employee satisfaction with their benefit scheme" and "Employee engagement" simultaneously. Even in this case, the result showed a relatively strong dependence, since the correlation coefficient was 0.715 . However, in this model, the regression coefficient of Employee satisfaction with their benefit scheme was statistically insignificant. Such situation is explained by the fact that the assessment of satisfaction with the employee benefit scheme and assessment of engagement are mutually correlated. The correlation between the assessment of satisfaction with the employee benefit scheme and assessment of employee engagement is 0.58 . Apparently, employee engagement also affects satisfaction with the employee benefit scheme.

Both cases of testing show that the level of engagement of line employees has a greater impact on their overall job satisfaction than the level of satisfaction with the current benefit scheme. Obviously, employee engagement is a crucial factor employers should pay attention to. Consequently, the issue was further analysed. Differences between individual generations are often referred to at present. The analysis investigated whether younger employees (often called Generation Y, i.e., born between 1980 and 2000) differ from the generation of older employees designated as Generation X (i.e., born between 1960 and 1980) in terms of employee engagement. The analysis focused on individual factors of engagement. The monitored variables were satisfaction with management, work atmosphere and potential personnel turnover rate.

It was established using the Mann-Whitney $\mathrm{U}$ test that there are statistically significant differences between the generations in the area of assessment of the work atmosphere. Table 1 shows the results.

Tab. 1: Differences in the assessment of employee engagement between Generation $\mathrm{X}$ and $\mathrm{Y}$

Mann-Whitney U Test (w/ continuity correction) by variable generation. Marked tests are significant at $\mathrm{p}<0.05000$

\begin{tabular}{|c|c|c|c|c|c|}
\hline Variable & $\mathrm{U}$ & $\mathrm{Z}$ & $\mathrm{p}$-value & $\begin{array}{c}\mathrm{Z} \\
\text { adjusted }\end{array}$ & p-value \\
\hline Management & 3770.500 & -1.13768 & 0.255256 & -1.14207 & 0.253424 \\
\hline
\end{tabular}




\begin{tabular}{|c|c|c|c|c|c|}
\hline Atmosphere & 3298.000 & -2.41452 & 0.015756 & -2.44271 & 0.014578 \\
\hline Personnel turnover & 4103.500 & -0.23780 & 0.812033 & -0.23953 & 0.810697 \\
\hline
\end{tabular}

Work atmosphere was investigated using several questions in the questionnaire. Questions were then identified in which different responses between individual generations were established. Table 2 was used as a basic underlying document to calculate the level of disagreement with the statement "My superior manager gives me recognition for good performance". Only $37.5 \%$ of employees from Generation X disagreed as opposed to $58 \%$ of respondents from Generation Y.

Tab. 2: Comparison of responses to the question "My superior manager gives me recognition for good performance"

\begin{tabular}{|c|c|c|c|c|c|}
\hline Generation & $\begin{array}{c}\text { Strongly } \\
\text { disagree }\end{array}$ & Disagree & Agree & $\begin{array}{c}\text { Strongly } \\
\text { agree }\end{array}$ & Sum \\
\hline X & 4 & 20 & 34 & 6 & 64 \\
\hline Y & 17 & 59 & 36 & 19 & 131 \\
\hline Sum & 21 & 79 & 70 & 25 & 195 \\
\hline
\end{tabular}

Source: own processing

The results show that younger employees (Generation Y) think they are given recognition for their good performance more frequently than the older generation (Generation $\mathrm{X}$ ).

The next statement to investigate employee engagement was: "There is usually a good atmosphere among colleagues at work". The table shows the absolute frequency of responses used as the underlying document to calculate the level of disagreement with the statement.

Tab. 3: Comparison of responses to the question "There is usually a good atmosphere among colleagues at work"

\begin{tabular}{|c|c|c|c|c|c|}
\hline Generation & $\begin{array}{c}\text { Strongly } \\
\text { disagree }\end{array}$ & Disagree & Agree & $\begin{array}{c}\text { Strongly } \\
\text { agree }\end{array}$ & Sum \\
\hline $\mathrm{X}$ & 11 & 30 & 19 & 4 & 64 \\
\hline $\mathrm{Y}$ & 47 & 66 & 12 & 6 & 131 \\
\hline Sum & 58 & 96 & 31 & 10 & 195 \\
\hline
\end{tabular}

Source: own processing

The level of disagreement of Generation $\mathrm{X}$ was lower (64\%) than the level of disagreement of Generation $\mathrm{Y}(86 \%)$ in this case as well. It means that younger employees also give a more positive general assessment in this case and they think the atmosphere among their peers at work is generally good. The third and last statement which was analysed was defined as follows: "My colleagues are willing to work and perform well". Table 4 shows the absolute frequency of responses to the statement.

Tab. 4: Comparison of responses to the question "My colleagues are willing to work and perform well"

\begin{tabular}{|c|c|c|c|c|c|}
\hline Generation & $\begin{array}{c}\text { Strongly } \\
\text { disagree }\end{array}$ & Disagree & Agree & $\begin{array}{c}\text { Strongly } \\
\text { agree }\end{array}$ & Sum \\
\hline $\mathrm{X}$ & 14 & 42 & 8 & 0 & 64 \\
\hline $\mathrm{Y}$ & 50 & 70 & 9 & 2 & 131 \\
\hline Sum & 64 & 112 & 17 & 2 & 195 \\
\hline
\end{tabular}

The level of disagreement of Generation $\mathrm{X}$ is also lower (87.5 $\%)$ than that of Generation Y $(91.5 \%)$. Nonetheless, the differences between individual generations are relatively small and it can be concluded that both generations have a good opinion of their colleagues and think they are willing to work and perform well. However, the opinion of Generation $\mathrm{Y}$ is stronger.

The Mann-Whitney U test was used to find out whether the established differences in the level of disagreement with individual statements are statistically significant. The results are shown in Table 5 .

Tab. 5: Verification of the statistical significance of established differences between Generation X and Y

Mann-Whitney U Test (w/continuity correction) by variable generations 1 Marked tests are significant at $\mathrm{p}<0.05000$

\begin{tabular}{|c|c|c|c|c|}
\hline Statement & $\mathrm{Z}$ & $\mathrm{p}$-value & $\mathrm{Z}$ & $\mathrm{p}$-value \\
\hline 1 & -1.88217 & 0.059814 & -2.00195 & 0.045291 \\
\hline 2 & -3.34818 & 0.000814 & -3.6311 & 0.000282 \\
\hline 3 & -1.95513 & 0.050569 & -2.22155 & 0.026314 \\
\hline
\end{tabular}

Source: own processing

Table 5 shows that in all three statements:

1. "My superior manager gives me recognition for good performance"

2. "There is usually a good atmosphere among colleagues at work".

3. "My colleagues are willing to work and perform well", statistically significant differences were established, the most significant differences being the second statement with the first statement being the least significant. The results indicate that employers should take into account the age structure of their personnel when managing work performance and developing incentive reward schemes since it is evident that there will be certain differences between these generations.

\section{Discussion}

Many studies have been devoted to the importance of employee engagement and no one disputes its value (Albrecht and Anglim, 2018; Jung and Yoon, 2018; Jena, Pradhan and Panigrahy, 2018; Siti and Nik, 2019). This study, however, established a very interesting fact - that employee engagement has an even greater effect on overall job satisfaction of employees than satisfaction with the benefit scheme. The conclusions of this study are extremely important considering the amounts of money spent by employers on benefit schemes and the attention paid to them (Jaworski et al., 2018; Purdon, 2018; Szeiner, Szobi and Sklenár, 2018; Sreenath et al., 2019), because they show that a more efficient way to increase job satisfaction (leading to higher retention and performance) is by way of the attention paid to developing work engagement, particularly the work atmosphere. It is not completely explicit whether job satisfaction affects the performance of employees in reality. Some studies state there is definitely a positive relationship (Octaviannand et al. 2017), while others emphasise a neutral relationship by contraries (Cimperman, 2016). The fact that the results of some studies show positive and others negative effects of employee satisfaction on work performance can result from operationalisation (definition) of job satisfaction as well as the method of measuring performance. The time factor is another important factor, i.e., satisfied employees need not necessarily increase their performance instantly but they can maintain a stable performance over time, which is an indisputable asset for an employer as well. There are other factors which can affect investigations into employee satisfaction, such as the industry. Albattah et al. (2017) established that the happiest personnel are those in the building industry. This was the conclusion of extensive research conducted in the USA which lasted the whole business cycle and where the selection group consisted of more than 13,000 respondents. Another important finding made by Albattah et al. was that satisfaction, or factors affecting it, changes in employees depending on the business cycle. Recession is characterised by growing demands for a higher salary and, on the other hand, demands for career growth go down. Hence, the importance of external motivation grows during a recession.

Some studies devoted to job satisfaction rank among factors affecting satisfaction factors classified by other authors as "employee engagement". A typical example is work atmosphere, 
which is ranked among factors affecting job satisfaction by some authors (Florea \& Amuza, 2015; Hitka et al., 2015; Janićijević et al. 2015; Octaviannand et al., 2017). Apparently, it is irrelevant how the terms are defined from the practical point of view, nonetheless, it is always necessary to verify the operationalisation of individual variables considering science and research. It has been confirmed that different operationalisation can lead to different results and conclusions.

Employee engagement was investigated in the studies conducted by Ćulibrk et al. (2018); Reissová, Šimsová a Hášová, 2017.; Victor \& Hoole, 2017; Rudaleva \& Mustafin, 2017; Aksoy et al., 2018. Culibrk et al. (2018) state that personnel working in manufacturing corporations are more satisfied and engaged than those working in the tertiary sector. Other interesting findings related to the length of employment and education. The longer people work in an organization, the lower satisfaction and engagement they show. Employees with higher completed education show lower engagement at work.

Obviously, work engagement is affected by a number of variables. As the conclusions of this study suggest, age and falling within the respective generation is an important variable, too. Although authors disagree about an exact specification of time for Generation $\mathrm{X}$ and $\mathrm{Y}$, generally, people born between 1960 and 1980 are considered Generation $X$ and the following generation (between 1980 and 2000) is considered Generation Y. Generation $\mathrm{Y}$ represents a substantial and constantly growing percentage of the work force on the labour market. The available studies show that attracting and retaining employees from Generation $\mathrm{Y}$ is rather complicated for businesses because Generation $\mathrm{Y}$ has different opinions compared to Generation $\mathrm{X}$ in many areas. The younger generation finds the image of the organization important, they expect and demand a higher standard of living and put emphasis on the balance between work and life. The research conducted in Olomouc on 350 respondents showed that employees from Generation Y find the financial remuneration, work team, job description and working hours the most important at work (Kasalová et al., 2015). Employees from Generation Y are also very ambitious, they tend to come up with new ideas and innovations which would bring better, faster and more effective results, they demand a modern work environment, good work atmosphere, good relationships with superior executives and open communication with other staff members. If an organization wants to retain staff members from Generation Y, it must make sure to provide its personnel with a pleasant work environment, which will considerably affect their loyalty and long-term work engagement. These employees find it important to have a certain kind of freedom, creativity and flexibility, they look for more demanding assignments and challenges, they are much more talented in using information technology, the feeling of being recognised is very important for them, as well as interest from other staff members and responsibility. Employees from Generation Y need to develop constantly, learn new things, train and share information (Moravcova-Skoludova \& Vlckova, 2018). The need for recognition is confirmed by the authors Naim \& Usha (2018), too. They state that personnel from Generation Y need to get feedback about their work results, they need to feel that they are given support by their superiors and peers, which can help share information with others, they need to develop, which can lead to better retention, build links to the organization and consequently, to their engagement. The research conducted by Valickas \& Jakštaite (2017) on 850 employees of one company confirmed that representatives of Generation $\mathrm{Y}$ are open to changes and they need to know why the work performed is important and whether the work will be useful and purposeful in the future. The research established that Generation $\mathrm{Y}$ needs superior managers who are willing to listen to their opinions and give them recognition. It was confirmed by this survey as well that not only wages, intangible benefits and development of competences are the most important incentives for representatives of Generation Y, but also self-esteem, work environment and relationships with colleagues and superior managers, recognition, and possibility being able to have their say. As the conclusions of the research suggest, these employees are very ambitious. Similar conclusions are stated in other surveys devoted to finding a place for Generation $\mathrm{Y}$ on the labour market (Civelek et al, 2017; Horáčková and Kopáček, 2018; Putri, Sjabadhyni and Mustika, 2018). The above-stated conclusions as well as other studies (Bencsik, Horváth-Csikós and Juhász, 2016) show that personnel managers must be able to respond to the specifics of individual generations and prepare incentive and retention schemes that take into account the differences between the generations.

\section{Conclusion}

The main objective of this study was to identify whether employee satisfaction is affected more by employee engagement or level of satisfaction with the employee benefit scheme. The regression analysis established that employee engagement is more closely related to overall employee satisfaction than satisfaction with the benefit scheme. The models in question proved that an increase in the assessment of engagement of one unit has a greater effect on overall job satisfaction (nearly $29 \%$ ) than an increase in satisfaction with the employee benefit scheme (only $21 \%$ ).

Due to the importance and significance of employee engagement, the survey investigated which of the three monitored factors (satisfaction with management, work atmosphere and potential personnel turnover rate) mostly affect the assessment of engagement. The Mann-Whitney $U$ test proved that assessment of the work atmosphere is the most important. Work atmosphere was therefore analysed in detail and individual statements were examined in detail in consideration of the age of the respondents (Generation $\mathrm{X}$ and $\mathrm{Y}$ ). Responses to statements were tested: "My superior manager gives me recognition for good performance", "There is generally a good atmosphere at work among my peers" and "My colleagues are willing to work and perform well".

The results show that there are statistically significant differences between the generations in their assessment of work atmosphere. The younger Generation Y appreciate the situation more positively than Generation X. This finding is important for practice. Employers should take into consideration for which generation they prepare their schemes, either incentives, development, performance or others. The schemes will likely be effective if they take into account the specifics of the respective generations. This topic should be investigated in detail due to its importance.

\section{Literature:}

1. Aksoy, C., Şengün, H. İ. and Yilmaz, Y.: Examination of the Relationship between Job Satisfaction Levels and Organizational Commitments of Tourism Sector Employees: A Research in the Southeastern Anatolia Region of Turkey. Electronic Journal of Social Sciences, 2018, Vol. 17, No. 65, pp. 356-365. https://doi.org/10.17755/esosder.343032

2. Albattah, M., Shan, Y., Goodrum, P. M. and Taylor, T. R.: Relationships between cycles of economic expansion in construction and craft workers' job satisfaction and preferences. Canadian Journal Of Civil Engineering, 2017, Vol. 44, No. 1, pp. 29-36. doi:10.1139/cjce-2016-0358

3. Albrecht, S. L. and Anglim, J.: Employee engagement and emotional exhaustion of fly-in-fly-out workers: A diary study. Australian Journal of Psychology, 2018, Vol. 70, No. 1, pp. 6675. https://doi.org/10.1111/ajpy.12155

4. Bencsik, A., Horváth-Csikós, G. and Juhász, T.: Y and Z Generations at Workplaces. Journal of Competitiveness, 2016, Vol.8, No. 3, pp. 90-106. https://doi.org/10.7441/joc.2016.03.06 5.Cimperman, S.: Vpliv zadovoljstva zaposlenih na produktivnost $\mathrm{v}$ Tiskarni Novo mesto, d.d. (Slovenian). RUO: Revija Za Univerzalno Odlicnost, 2016, Vol. 5, No. 2, pp. 175186.

6. Civelek, M. E., Çemberci, M., Așçı, M. S. and Öz, S.: The Effect of the Unique Features of Y Generation on Organizational Commitment. Journal of History, Culture \& Art Research / 
Tarih Kültür ve Sanat Arastirmalari Dergisi, 2017, Vol. 6, No. 6, pp. 336-349. https://doi.org/10.7596/taksad.v6i6.1353 7. CZSO. Zaměstnanost. Nezaměstnanost. [online]. 2019 [cit. 2019-03-20]. Retrieved from: https://www.czso.cz/csu/czs o/zamestnanost_nezamestnanost_prace).

8. Culibrk, J., Delić, M., Mitrović, S. and Ćulibrk, D.: Job Satisfaction, Organizational Commitment and Job Involvement: The Mediating Role of Job Involvement. Frontiers In Psychology, 2018, Vol 9, pp. 132. Doi:10.3389/fpsyg.2018.00132/full

9. D'AMBROSOVÁ, Hana. Abeceda personalisty 2015. 6. aktualiz. vyd. Olomouc: Anag, 2015. Práce, mzdy, pojištění. ISBN 978-80-7263-934-2.

10. Florea, R. and Amuza, A.: Identifying company values and employee satisfaction in modern organizations - a case study on the methods used to diagnose employee satisfaction and recognize company values. Annals of The University of Oradea: Economic Science, 2015, Vol. 25, No. 1, pp. 11651171.

11. Gosse, B. and Hurson, C.: Assessment and improvement of employee job-satisfaction: a full-scale implementation of MUSA methodology on newly recruited personnel in a major French organisation. Annals Of Operations Research, 2016, Vol. 247, No. 2, pp. 657-675. Doi:10.1007/s10479-015-1811-y

12. Hitka, M., Závadská, Z., Jelačić, D. and Balážová, Ž.: Qualitative Indicators of Company Employee Satisfaction and Their Development in a Particular Period of Time. Wood Industry / Drvna Industrija, 2015, Vol. 66, No. 3, pp. 235-239. Doi:10.5552/drind.2015.1420

13. Horáčková, L. and Kopáček, M.: Generation Y on the labour market: regional analysis of the Visegrad Group countries. Geografické informácie/Geographical Information, 2018, Vol. 22, No. 1, pp. 118-130. doi 10.17846/GI.2018.22.1.118-130.

14. Janićijević, N., Kovačević, P. and Petrović, I.: Identifying organizational factors of job satisfaction: the case of one Serbian company. Economic Annals, 2015, Vol. 60, No. 205, pp. $73-$ 104.

15. Jaworski, C., Ravichandran, S., Karpinski, A. C. and Singh, S.: The effects of training satisfaction, employee benefits, and incentives on part-time employees' commitment. International Journal of Hospitality Management, 2018, Vol. 74, pp. 1-12. https://doi.org/10.1016/j.ijhm.2018.02.011

16. Jena, L. K., Pradhan, S. and Panigrahy, N. P.: Pursuit of organisational trust: Role of employee engagement, psychological well-being and transformational leadership. Asia Pacific Management Review, 2018, Vol. 23, No. 3, pp. 227-234. https://doi.org/10.1016/j.apmrv.2017.11.001

17. Jung, H. S. and Yoon, H. H.: Improving frontline service employees' innovative behavior using conflict management in the hospitality industry: The mediating role of engagement. Tourism Management, 2018, Vol. 69, pp. 498-507. https://doi.org/10.1016/j.tourman.2018.06.035

18. Kasalová, B., Seitlová, K. and Seitl, M.: Work Environment Preferences of Generation Y in Relation to Attachment Theory. Proceedings of the European Conference on Management, Leadership \& Governance, 2015, pp. 607.

19. Madan, S.: Moving from employee satisfaction to employee engagement. CLEAR International Journal of Research In Commerce \& Management, 2017, Vol. 8, No. 6, pp. 46-50.

20. Minder, S. and Balina, S.: Human Resource Management's Marketing Approach and Its Contribution Towards EmployeeSatisfaction. Expert Journal of Business and Management, 2015, Vol. 3, No. 2, pp. 194-204. doi:10.15580/gjbms.2 013.5.020313430

21. Moravcova-Skoludova, J. and Vlckova, A.: The Factors Influencing Satisfaction of Generation Y in the Workplace in the Czech Republic. Economic \& Social Development: Book of Proceedings, 2018, pp. 335-341.

22. Naim, M. F. and Usha, L.: Development and retention of Generation Y employees: a conceptual framework. Employee relations, 2018, Vol. 40, No. 2, pp. 433-455. doi:10.1108/er-092016-0172

23. Octaviannand, R., Pandjaitan, N. K. and Kuswanto, S.: Effect of Job Satisfaction and Motivation towards Employee's Performance in XYZ Shipping Company. Journal Of Education And Practice, 2017, Vol. 8, No. 8, pp. 72-79.
24. Petrović, I. B., Vukelić, M. and Čizmić, S.: Work Engagement in Serbia: Psychometric Properties of the Serbian Version of the Utrecht Work Engagement Scale (UWES). Frontiers in Psychology, 2017, Vol. 8. https://doi.org/10.33 89/fpsyg.2017.01799/full

25. Prayogo, L., Pranoto, B. A. S. and Purba, H. H.: Employee satisfaction analysis with human resource index. Management Science Letters, 2017, Vol. 7, No. 5, pp. 233-240. doi:10.5267/j.msl.2017.2.003

26. Purdon, E.: Employee Benefits: Thinking beyond the Paycheck. Journal of Financial Service Professionals, 2018, Vol. 72, No. 3, pp. 11. Retrieved from http://search.ebscohost.co $\mathrm{m} / \operatorname{login}$. asp $\mathrm{x}$ ?direct $=$ true $\& \mathrm{db}=\mathrm{edb} \& \mathrm{AN}=129329403 \&$ lang $=\mathrm{cs} \&$ site $=$ eds-live

27. Putri, S., Sjabadhyni, B. and Mustika, M. D.: "Making Generation Y Stay": The Mediating Role of Organizational Commitment. Psikohumaniora: Jurnal Penelitian Psikologi, 2018, Vol. 2, pp. 141-152. https://doi.org/10.21580/pjpp. v3i2.2513

28. Rani, S. and Kamalanabhan, S.: Work / Life Balance Reflections on Employee Satisfaction. Serbian Journal of Management, 2011, Vol. 6, No. 1, pp. 85. doi: $10.5937 / \mathrm{sjm} 1101085 \mathrm{r}$

29. Siti A. O. and Nik H. N. M.: Linking employee engagement towards individual work performance through human resource management practice: From high potential employee's perspectives. Management Science Letters, 2019, Vol. 7, pp. 1083. https://doi.org/10.5267/j.msl.2019.3.016

30. Szeiner, Z., Szobi, Á. amd Sklenár, D.: Employee Benefits Practice in Slovakia. Ad Alta: Journal of Interdisciplinary Research, 2018, Vol. 8, No. 2, pp. 246-253. Retrieved from http://search.ebscohost.com/login.aspx?direct=true $\& d b=a 9 h \& A$ $\mathrm{N}=134101978$ \&lang=cs\&site=eds-live

31. Reissová, A., Šimsová, J., and Hášová, K.: Gender Differences in Employee Engagement. Littera Scripta, 2017, Vol. 2, pp. 84-94.

32. Rudaleva, I. and Mustafin, A.: The Impact of Stress Stability on Job Satisfaction and the Quality of Human Capital. Journal of History Culture and Art Research, 2017, Vol. 6, No. 5, pp. 333341. doi:http://dx.doi.org/10.7596/taksad.v6i5.1252

33. Sreenath, S., Mohan, P. A. and Lavanya, M. P.: Employee Benefits and its Effect on Productivity at Semcon India Private Limited, Bangalore. SDMIMD Journal of Management, 2019, Vol. 10, No. 1, pp. 55-64. Retrieved from http://search.ebscoho st.com/login.aspx?direct=true $\& d b=e d b \& A N=135615924 \&$ lang= cs\&site $=$ eds-liv

34. Valickas, A., and Jakštaitè, K.: Different Generations'attitudes Towards Work and Management in The Business Organizations. Human Resources Management \& Ergonomics, 2017, Vol. 11, No. 1.

35. Victor, J. and Hoole, C.: The influence of organisational rewards on workplace trust and work engagement. SA Journal of Human Resource Management/SA Tydskrif vir Menslikehulpbronbestuur, 2017, Vol. 15, No. 0, pp. 853. https://doi.org/ 10.4102/sajhrm.v15i0.853

36. Amin, S., Arshad, R. and Ghani, R. A.: Spousal Support and Subjective Career Success: The Role of Work-Family Balance and Career Commitment as Mediator. Jurnal Pengurusan, 2017, Vol. 50, pp. 1-15. ISSN 01272713.

Primary Paper Section: A

Secondary Paper Section: AE, AN 